John R. Dupuche ${ }^{1}$

Australian Catholic University

\title{
Nostra aetate - stages of creation, with a particular focus on paragraph no. 2 and the people involved in its development
}

\section{Introduction}

The dramatic story of the genesis of The Declaration of the Relation of the Church to Non-Christian Religions (Nostra aetate) is not readily available except in the broad accounts of Vatican II as a whole. This paper focuses on one dramatic story. Where did Nostra aetate originally spring from? Who were the major players? What were the various issues that surrounded its development? What is the history of the major phrases in paragraph 2 of Nostra aetate? The gestation and birth of the text was uncertain from start to finish and the result was a surprise, a largely unexpected child of the Council.

While many welcomed this 'watershed statement', others rejected it. The non-reception has had profound consequences, schism no less. An ac-

1 Rev. Dr. John Dupuche is Pastor of Nazareth Parish, Ricketts Point, Melbourne. He is senior lecturer at the University of Divinity, Honorary Fellow at the Australian Catholic University, and chair of the Catholic Interfaith Committee of the Archdiocese. He has a doctorate in Sanskrit, specialising in Kashmir Shaivism and is particularly interested in its interface with Christianity. His book Abhinavagupta: the Kula Ritual as Elaborated in Chapter 29 of the Tantraloka was published in 2003; Jesus, the Mantra of God in 2005. He has written many articles in these fields. 
count of the bitter reaction of Archbishop Lefebvre and the Society of Saint Pius $\mathrm{X}$ is given in some of its essential details.

The drama surrounding Nostra aetate is not over.

The genesis of the major phrases of Nostra aetate paragraph 2, starting with Pius XII - a major but forgotten figure in this story - is given in the appendix.

\section{The genesis of Nostra aetate}

During his time as Apostolic Delegate in Istanbul Archbishop Angelo Roncalli, the future Pope John XXIII, had been deeply troubled by his inability to do more than bring individual and limited help to the Jews who were being persecuted. ${ }^{2}$ When therefore, on 13 June 1960, the French Jewish scholar, Jules Isaac, asked if the forthcoming Council could do away with all past teaching on anti-Semitism, ${ }^{3}$ John XXIII responded positivity and on 18 September, three months after founding the Secretariat for Promoting Christian Unity, received Augustin Cardinal Bea in private audience and gave him an explicit verbal mandate to prepare a schema on the Jews. ${ }^{4}$ Remarkably, along with the document on religious liberty this schema was the first conciliar text entrusted to the Secretariat, before even the schema on ecumenism. ${ }^{5}$

During the $37^{\text {th }}$ and $38^{\text {th }}$ General Congregations, September 30 and October 1, 1963, Archbishop Ngo dinh Thuc, brother of Vietnam's President Ngo dinh Diem, complained that the Decree De Oecumenismo, of which the Fathers had only the first three chapters, did "not provide an adequate presentation of the Church for non-Christians. The result, he said, is that the Church would remain for non-Christians an almost unintelligible organism". ${ }^{6}$ Cardinal Bueno y Monreal of Spain and Cardinal Doi of Japan, and most emphatically Bishop

\footnotetext{
R. Laurentin. Bilan du concile, Histoire-textes-commentaires avec une chronique de la quatrième session. Paris 1966. p. 129.

M. Ruokanen. The Catholic Doctrine of Non-Christian Religions according to the Second Vatican Council. Leiden 1992. p. 35.

R. M. Wiltgen. The Rhine Flows into the Tiber. New York City 1966. p. 167.

Laurentin. Bilan du concile. pp. 128-129.

Council Daybook Vatican II. Floyd Anderson (ed.). Washington DC 1965. Vol. 1, p. 151.
} 
Da Veiga Coutinho of India made similar comments. ${ }^{7}$ In this way the impetus was given for the Council to address the subject of non-Christian religions.

The final declaration, Nostra Aetate, is all the more surprising given that the Church throughout its history has entertained a mostly hostile and negative attitude toward non-Christian religions. The Gospel of John 1.9 and Acts 17.22-23, it true, have a more positive view, and the early Church Fathers state on occasion that the pagans also have their prophets, and propose ideas such as the logos-spermatikos. Notably, on his return from his visit to Sultan al-Malik al-Kâmil in 1220, Francis of Assisi composed a rule, accepted by his friars at the General Chapter of the Mats in 1221. Its chapter sixteen reads:

Indeed the friars, who go, can conduct themselves spiritually among [the Muslims] in two manners. One manner is, that they cause no arguments nor strife, but be subject "to every human creature for God's sake" (1 Pt 2:13) and confess themselves to be Christians. The other manner is, that, when they have seen that it pleases God, they announce the word of God, so that they may believe in God the Omnipotent, Father and Son and Holy Spirit, the Creator of all things, (and) in the Redeemer and Saviour, the Son, and that they may be baptized and become Christians, because "he who has" not "been reborn of water and the Holy Spirit cannot enter the Kingdom of God" (cf.Jn 3:5).

It is a remarkable text, for in a few sentences Francis rejects the aim and objectives of the Crusades which was to conquer the Holy Land by military means. It stands out as an exception to traditional attitudes. Not surprisingly the rule did not obtain papal approval so that it is called the Regula non-bullata. The Regula bullata, officially approved by Pope Honorius III on 29 November 1223, reduces the extraordinary paragraph to just a couple of bland sentences in its chapter 12:

Let whoever of the friars who by divine inspiration wants to go among the saracens and other infidels seek permission for that reason from their minister provincial. Indeed the ministers are to grant permission to go to none, except those who seem to be fit to be sent.

By and large, non-Christian religions were seen as the work of the devil. The Church had to wait till the encyclical Evangelii Praecones of Pius XII (2 June

J. M. Oesterreicher. 'Declaration on the Relationship of the Church to Non-Christian Religions', in Commentary on the Documents of Vatican II. Herbert Vorgrimler (ed.) New York and London 1967-1969. Vol. 3, p. 86. 
1951) $)^{8}$ for a significant change from this view. ${ }^{9}$ That encyclical states "...the Catholic Church neither despises nor rejects [neque despexit neque respuit] the doctrinal teachings of other peoples." That curiously negative phraseology represents a significant change of attitude. In the past the Church had in fact despised and rejected the doctrinal teachings of other peoples; now it does not. This phraseology will be maintained in Nostra aetate. Pius XII also speaks of the wish "to bring to completion as much as possible" (quam maxime perficere). An element of this support is also found in the final document.

On $22^{\text {nd }}$ November 1963 Cardinal Bea presented a text to be included as chapter 4 of the De Ecumenismo, a short text of 42 lines prepared over the space of two years, entitled "The Attitude of Catholics Toward Non-Christians, Particularly Toward the Jews". ${ }^{10}$ Only three lines concerned non-Christian religions in general; all the rest of the text concerned Jews. ${ }^{11}$

That chapter 4 provoked a great debate. Coadjutor Bishop Michael Rodrigues of Belgaum, India, warned that it would cause trouble in Arab nations and Asiatic countries since it omitted any reference to their revered religions. He proposed that chapter 4 be either eliminated or further chapters added on Hinduism, Islam etc. ${ }^{12}$ Bishop Vito Chang, former Bishop of Sinyang, China, wished to see mention made of Buddhists, Confucionists and Shintoists. ${ }^{13}$ Some African bishops asked that a reference be made to animism. In the long run Confucianism and Shintoism were not considered to be true religions but ethical or social systems ${ }^{14}$ and no reference was made to Sikhs and Parsis either because of their close connection with other great religions or because of their small numbers.

In the context of these heated responses, Paul VI took several important steps. In his Easter Message, 29 March 1964, he proclaimed: "Every religion contains a ray of the light which we must neither despise nor extinguish..." On Pentecost Sunday, 17 May 1964, he announced the establishment

8 Acta Apostolicae Sedis 1951, pp. 497-528. Official French translation in „Nouvelle Revue Théologique" 73 (1951) 854-868.

$9 \quad$ Laurentin. Bilan du concile. p. 297.

10 Council Daybook Vatican II, Vol., 1. pp. 249-250.

11 Ruokanen. p. 37.

12 Council Daybook Vatican II. Vol. 1, p. 293.

13 Council Daybook Vatican II. Vol. 1, p. 294.

14 J. Masson. 'La déclaration sur les religions non-chrétiennes', „Nouvelle Revue Théologique” 87 (1965) 1066-1083. p. 1071. 
of a Secretariat for non-Christians as an organism distinct from the Sacred Congregation for the Evangelization of Peoples. It was to be headed by Cardinal Marella who had been Apostolic Internuncio in Japan during World War II. ${ }^{15}$ Its competence was defined in its constitution:

To search for methods and ways of opening a suitable dialogue with non-Christians. It should strive, therefore, in order that non-Christians come to be known honestly and esteemed justly by Christians, and that in their turn non-Christians can adequately know and esteem Christian doctrine and life. ${ }^{16}$

On 6 August 1964, he publishes his first encyclical, Ecclesiam suam whose emphasis, which is that of the Council as a whole, is dialogue, not just discussion but all forms of relationship with both individuals and communities in ways that might lead to mutual assistance. This was a departure from the norm. Other Councils were concerned mainly with reform or renewal. Although some did involve establishing relationships, such as with the Greeks at the Lyons II (1274) (at which representatives of the Abaqa Khan of the Likhanate were present) or with the Armenians at the Council of Basel-Ferrara-Florence (1431-1449), the relationship was undertaken to solve an issue. There was no reflexion on the meaning of dialogue, and certainly no consideration of relationship with other religions. ${ }^{17}$

Ecclesiam suam sets out the relationships in a series of concentric circles. The first circle is with fellow Christians and will lead to the great texts on ecumenism. The second circle comprises those who worship the one supreme God, namely the Jews in the first instance but also the Muslims. ${ }^{18}$ Then in the next circle the religions of Asia and Africa. He does not adopt an uncritical attitude and states

Indeed, honesty compels us to declare openly our conviction that the Christian religion is the one and only true religion, and it is our hope that it will be acknowledged as such by all who look for God and worship Him ${ }^{19}$

\footnotetext{
15 Wiltgen. The Rhine Flows into the Tiber. p. 172.

16 Regimini Ecclesiae para. 99.

17 Laurentin, Bilan du concile, p. 292.

18 Ecclesiam suam para. 107.

19 Ecclesiam suam para. 107.
} 
but he goes on to say:

But we do not wish, however, to fail to respect [nolumus ...non respicere] the good things, spiritual and moral [bona spiritualia et moralia], of the various non-Christian religions, and we desire to join with them in advancing [provehere] and defining the common ideals of religious liberty, human brotherhood, culture, social welfare and civil order. ${ }^{20}$

The key phrases 'do not wish to fail to respect', 'the good things, spiritual and moral' 'advancing' will be echoed in the final text.

Chapter 4 of De Oecumenismo was then changed into an appendix of 70 lines entitled 'Concerning Jews and non-Christians', and was presented to the Council Fathers on September 25, 1964. The most visible change to the version of November $3^{\text {rd }} 1963$ was a completely reworded text on non-Christians religions in addition to Judaism. ${ }^{21}$ It speaks of the brotherhood of all people under the one God who is called Father.

Deep expressions of concern continued, especially with regard to the whole Middle East where the long-standing political antipathies were still keenly felt and where refugee camps were an on-going issue. ${ }^{22}$ On November 18, 1964, for example, Ignace Cardinal-Patriarch Tappouni, of the Syrian Patriarchate of Antioch, again expressed his fears. ${ }^{23}$ Yves Congar in his Council Diary for 3 May 1965 echoed those fears, concerned lest

Jews might for their part exploit the text, as they have already done, to find there a justification for their presence in Palestine. Because they are sons of the Covenant, they have a right to the land of the Covenant. [...] On the other hand, the declaration might compromise the situation of the Christians and lead to the burning of churches and the murder of Christians, both Coptic and Catholic. ${ }^{24}$

The matter would become calmer if the text did not focus simply on the Jews and the inevitable political problems, but opened out to include all the religions of the world. ${ }^{25}$ José Cardinal Bueno y Montreal, of Seville, for his part

\footnotetext{
20 Ecclesiam suam para. 108.

21 Ruokanen. The Catholic doctrine... p. 38.

22 Laurentin. Bilan du concile. pp. 84-85.

23 Wiltgen. The Rhine Flows into the Tiber. p. 169.

${ }_{24}$ Yves Congar. Mon Journal du Concile, présenté et annoté par Eric Mahieu. Paris 2002. Vol. II, pp. 364-365.

25 Masson, 'La déclaration sur les religions non-chrétiennes'. p. 1068.
} 
noted that politics would be avoided if there were no mention of the Jews at all in the title. The title of the declaration should read 'On the Relationship of the Church to Non-Christian Religions.' He made further suggestions which were to a great extent followed in the final text. Thus,

The text dealt first with non-Christian religions in general, then with Hinduism and Buddhism by name, but briefly. Islam was treated next and at greater length because of its absolute monotheism and numerous links with revelation as contained in the Scriptures. The Jews were treated next, at even greater length, because of their singular destiny in the plan of salvation. In conclusion, the text ruled out all discrimination, both in theory and in practice. ${ }^{26}$

All these discussions and debates lead eventually to a rewriting of the 'Concerning Jews and non-Christians' which was then introduced as a schema of its own and not as an appendix to De Ecumenismo. It was now entitled 'On the relationship of the Church to non-Christian religions', 177 lines in length. It was not discussed during the Third Session of the Council due to lack of time but was accepted in the $127^{\text {th }}$ General Congregation on 20 November with 1651 placet versus 99 non placet. $^{27}$

It was with a sense of pride and a certain amazement that Cardinal Bea, on that same day, November 20,1964, described the text as a sort of "mustard seed in that it has grown from a brief statement on the Jews into a treelike document in which all non-Christian religions are finding their place." He noted that "...For the first time in the history of ecumenical councils, the principles dealing with non-Christians are set forth in solemn form." 28 Laurentin for his part expressed his surprise that Nostra aetate, more novel that the statements on collegiality or religious freedom, did not, for all the debates surrounding it, cause serious difficulties in the Council. ${ }^{29}$

A few slight changes - consisting mainly in the rearrangement of phrases - were made to the final text which was approved by the Council Fathers on 28 October 1965.

The "treelike document" is, however, minimalist. The Paulist, Fr Thomas Stransky, adds a note of sobriety: "...What is said in the declaration may seem

\footnotetext{
26 Wiltgen. The Rhine flows into the Tiber. p. 174.

27 Ruokanen. The Catholic doctrine... p. 40.

28 Council Daybook Vatican II. Vol. 2, p. 296.

29 Laurentin. Bilan du concile. p. 297.
} 
naïve in centuries to come, but at the present ... it would be difficult for the council to come up with any more than it has." ${ }^{30}$

What does "true and holy" mean? What is the dogmatic status of Nostra aetate paragraph 2? Regarding this latter question, at a press conference on the $16^{\text {th }}$ May 2012, Cardinal Koch, head of the Holy See's Commission for Religious Relations with the Jews stated that "All the doctrinal decisions of the Church are binding on a Catholic, including the Second Vatican Council and all its texts." But a few days later, on $21^{\text {st }}$ May, Cardinal Walter Brandmüller insisted that Nostrae aetate was "not binding".

The decision to leave the matter open-ended was partly tactical.

[Cardinal] Cicognani's decision to expand it was essentially a tactical move meant to retain control of the difficult diplomatic situation [viz. regarding the situation of Christians in other religious contexts], but it proved to be providential in redefining the identity of the schema as a first adoption by the ecclesiastical magisterium of a position on the subject of interreligious dialogue. The second aspect of the identity of the schema [viz. the Church's attitude to other religions] (the real meaning of which the bishops had little, if any, comprehension of at the time) would emerge when its richness was revealed during the phase of reception. ${ }^{31}$

Theologians from both camps, Joseph Ratzinger from the conservative camp, and Karl Rahner and Yves Congar from the other side, see this openendedness as a commission to later generations to develop these ideas more clearly. ${ }^{32}$

Nostra aetate is easily the most important document of Vatican II to deal with relations with non-Christians but other texts touch briefly on this subject. Thus the Council in its Dogmatic Constitution on the Church (Lumen gentium), echoing phrases in Nostra aetate, states

Through her work, whatever good is in the minds and hearts of men, whatever good lies latent in the religious practices and cultures of diverse peoples, is not only saved from destruction but is also cleansed, raised up and perfected unto the glory of God, the confusion of the devil and the happiness of man. ${ }^{33}$

30 Council Daybook Vatican II. Vol. 3, p. 140.

31 History of Vatican II. Giuseppe Alberigo (ed.) English version edited by Joseph A. Komonchak. Maryknoll, NT 2006. Vol. V, p. 230.

32 A. M. Nolan. A privileged moment: dialogue in the language of the Second Vatican Council, 1962-1965. New York 2006. p. 93.

33 'Dogmatic Constitution on the Church' (Lumen Gentium). para. 17. 
The Pastoral Constitution on the Church in the Modern World (Gaudium et spes) also acknowledges that truth can be found in all religions.

For their part, however, all believers of whatever religion always hear His revealing voice in the discourse of creatures. When God is forgotten, however, the creature itself grows unintelligible. ${ }^{34}$

The Council, in other documents, speaks of uncovering "with gladness and respect those seeds of the Word which lie hidden among [other traditions]" ${ }_{35}$ It states that "human values common to all mankind" require Christians to "collaborate with those who do not profess Christianity". ${ }^{36}$

\section{The rejection of Nostra aetate}

The Coetus Internationalis Patrum, "a network with vague limits" ${ }^{37}$ headed by Bishops Lefebvre, Sigaud and Carli, was bitterly opposed to Nostra aetate. On 11 October 1965, shortly before the final vote, they presented "an implacable condemnation of the declaration" which was "above all a hostile disavowal of the work of the [Secretariat for Promoting Christian Unity] and, in general, of the entire activity of those in charge of the conciliar assembly."38 Yves Congar's Council Diary of 13 October 1965 shows his exasperation: "They are stuck in a narrow system, in ready-made formulas and they reject or condemn without facing any of the issues. They arouse reactions as simplistic as their own." ${ }^{39}$ John Oesterreicher states "[Marcel Lefebvre] is a man who objected to the Council as a whole. Like his colleagues in that committee, he was, I am sorry to say, anti-vernacular, anti-Protestant, anti-Jewish, anti-everything." ${ }^{30}$

It was not the section on the Jews that caused most difficulty, but the very idea that there could be dialogue with non-Christians. Either this dia-

34 'Pastoral Constitution on the Church in the Modern World' (Gaudium et Spes). para. 37.

35 'Decree on the Church's Missionary Activity' (Ad Gentes Divinitus), 7 December 1965. para. 11.

36 'Decree on the Apostolate of Lay People' (Apostolicam Actuositatem), 18 November 1965. para. 27.

37 B. Tissier De Mallerais. The biography. Marcel Lefebvre. Kansas City, Missouri 2004. p. 293.

38 History of Vatican II. Alberigo (ed.). Vol. V, p. 212.

39 Congar. Mon Journal du Concile. Vol. II, p. 433.

${ }^{40}$ John M. Oesterreicher. The new encounter between Christians and Jews. New York 1986. pp. 272-273. 
logue was just "peaceful conversation" in which case it could become "puerile". On the other hand, if it meant dialogue in a religious sense it disobeyed the command to preach the truth of Christ Jesus. They rejected the idea of an "area of agreement" or a "common denominator". They were particularly opposed to paragraphs 2 and $3 .{ }^{41}$ This total opposition eventually led to full scale schism, as we shall see.

Perhaps the most famous contribution of John Paul II to the work of interreligious relations was the meeting in Assisi which he announced on 25 January 1986, to which Cardinal Ratzinger objected and which he did not attend. Archbishop Lefebvre was completely hostile. In his sermon on Easter Sunday, 1986, at Ecône, he states:

We are faced with a serious dilemma which I believe, has never existed in the Church: the one seated on the chair of Peter takes part in the worship of false gods. What conclusions will we have to draw, perhaps in a few months' time, faced with these repeated acts of taking part in the worship of false religions, I do not know. ${ }^{42}$

It is a veiled threat.

The meeting in Assisi takes place later in October that year. Eighteen months later, on 7 June 1988 Archbishop Lefebvre states,

Is it conceivable that, since the 1960's, the Apostolic See has been occupied by Popes who have been the cause of the 'auto-demolition of the Church', and spreading within it 'the smoke of Satan'? ${ }^{43}$

At Ecône a few weeks later, on 30 June 1988, Archbishop Lefebvre and Bishop de Castro Mayer ${ }^{44}$ ordain four bishops, wishing to save the Church by dividing the Church.

Undaunted by Lefebvre's refusal of dialogue in a religious sense, John Paul II examines at some length the whole idea of interreligious dialogue ${ }^{45}$

${ }^{41} \quad$ History of Vatican II, Alberigo (ed.). Vol. V, p. 213.

42 Tissier. The biography. Marcel Lefebvre. p. 536.

43 Postface by Marcel Lefebvre, in Daniel Le Roux, Peter, Lovest Thou Me? John Paul II: pope of tradition or pope of revolution? Gladysdale, Vic 1989. No page number.

${ }_{44}$ Tissier. The biography. Marcel Lefebvre, pp. 562-564.

45 John Paul II. Novo millenio ineunte. para. 54-56. 
and insists that the missionary duty also involves "an attitude of profound willingness to listen" ${ }^{46}$ But his words fall on deaf ears.

Many years later on 27 October 2011 in Assisi, Pope Benedict XVI takes part with other religions at a meeting whose character he changed to emphasize social cooperation between religions and to prevent any suggestion that other religions were ways to the same God. Whereas John Paul II spoke of the divine realities and how the Holy Spirit is present in the prayers of other religions, Benedict spoke only about the human dimension. Despite these precautions, the reaction of Bishop Fellay, successor to Archbishop Lefebvre as Superior General of the Society of Saint Pius X, was similarly intense. He spoke of the confused irenicism of Assisi and said:

The Divine Word [Verbe de Dieu] was publicly placed on the same level as Olokun, the Word of God [la Parole de Dieu] at the level of the Veda, the divine Wisdom on an equal basis with syncretistic humanism. ${ }^{47}$

In a nostalgically quaint manner, Bishop Fellay then called for acts of reparation, such as Exposition of the Blessed Sacrament, Masses, Stations of the Cross, Rosaries, conferences etc. ${ }^{48}$

Despite such statements, negotiations between the Society and the Vatican continued. On 2 December 2011, Mgr Fernando Ocáriz, vicar general of Opus Dei and key papal negotiator with SSPX, states that there is space for "legitimate theological freedom" of explanation; that the elements in Council documents which were "not strictly doctrinal" required only "respect and gratitude"; and that "the interpretation of the innovations" must be done according to what Pope Benedict has called the "hermeneutic of reform, of renewal within continuity." Vatican II must not be seen as a "rupture" with tradition, as the Society maintains. ${ }^{49}$ Mgr Ocáriz makes no specific mention of interreligious relations.

\footnotetext{
46 John Paul II. Novo millenio ineunte. para. 56.

47 Source: VIS/Apic/Imedia/Zenit/KTO/fsspx.org - DICI (3.11.11).

48 Source: FSSPX/MG - DICI n²43 (28.10.11).

49 Fernando Ocáriz. The Tablet 10 December 2011. p. 28.
} 


\section{Concluding reflections}

In 2013, Pope Benedict XVI entered into well-deserved retirement. How will Pope Francis handle the immense vitality that has sprung from Nostra aetate, its hopes, it possibilities, its dangers? Like a bird released from its cage, this short paragraph 2 has a life of its own; how will Pope Francis accompany it into the future? Will SSPX ever be reconciled? What new forms of spirituality will result, new insights into the mystery of Christ? We look forward to the on-going fruitfulness of Nostra aetate which is like a 'horn of plenty' pouring out blessing upon blessing. 
Nostra aetate - stages of creation, with a particular focus on paragraph no. 2...

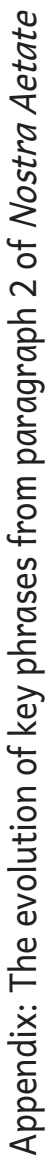

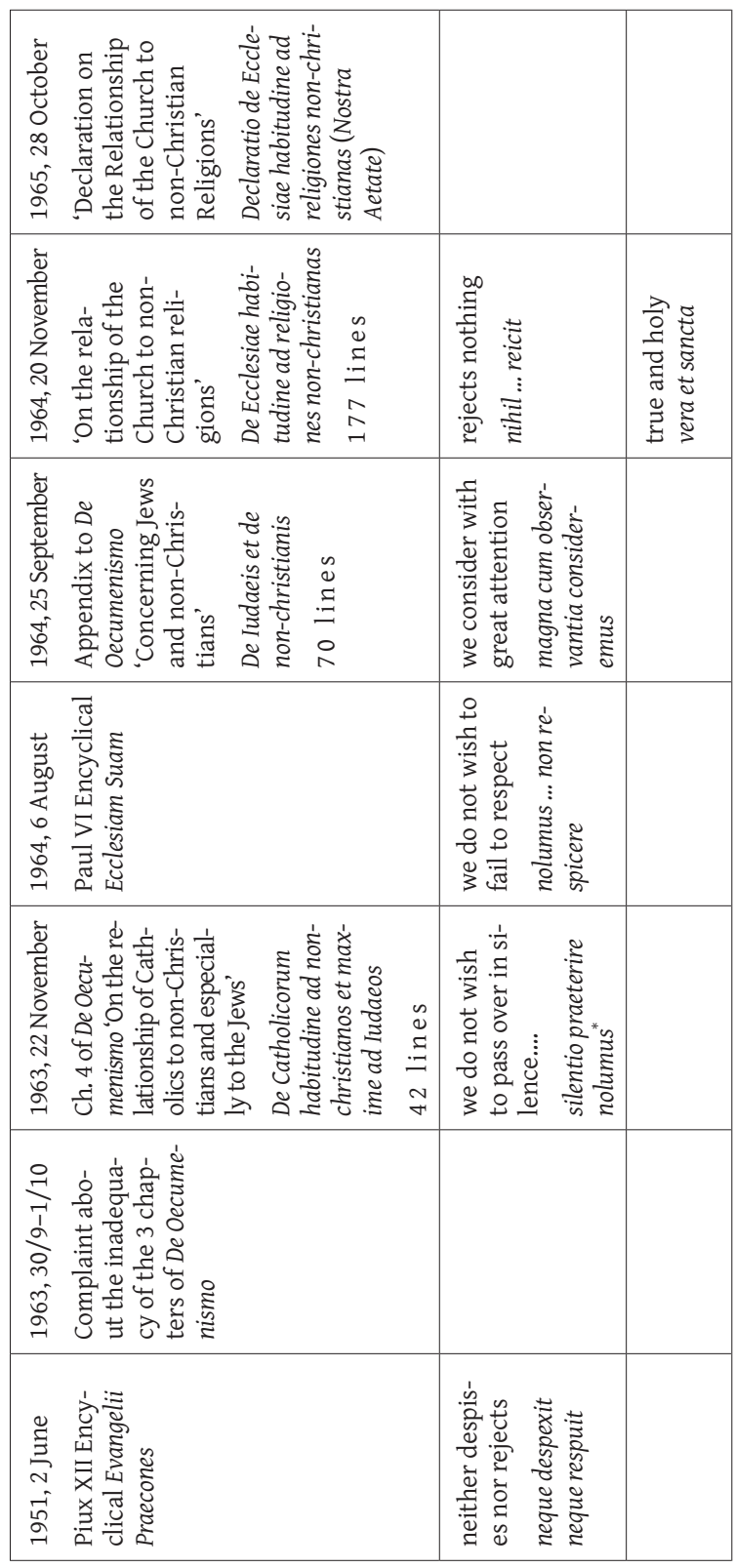

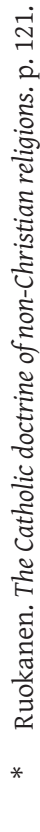


John R. Dupuche

\begin{tabular}{|c|c|}
\hline 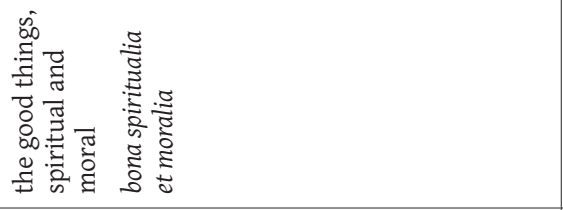 & 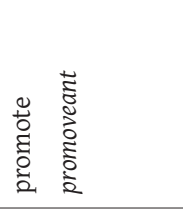 \\
\hline  & \\
\hline 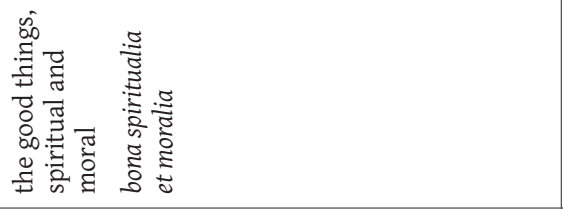 & 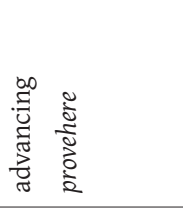 \\
\hline 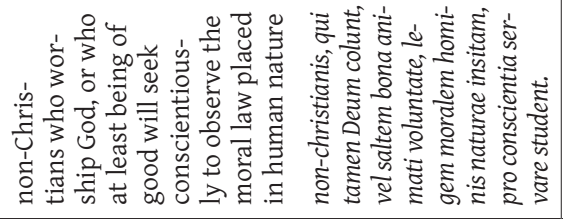 & \\
\hline 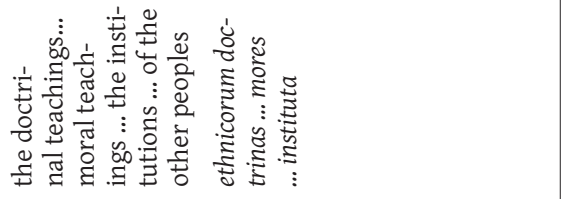 &  \\
\hline
\end{tabular}


Nostra aetate - stages of creation, with a particular focus on paragraph no. $2 \ldots$

\section{Summary}

Nostra aetate - stages of creation, with a particular focus on paragraph no. 2 and the people involved in its development

Nostra aetate began as an important statement concerning the relations of the Church with the Jews but soon developed into a highly significant text on the relationship of the Church to all the religions of the world. While there been many works on the theology of Nostra aetate, there are few studies that present in detail the major personages and stages, the crucial issues and opposing forces surrounding this prophetic document. This article seeks to address this lacuna.

The article also gives special attention to key phrases from paragraph 2 that show an extraordinary shift from millennial attitudes, among which "the Church does not reject what is truly and holy in these religions".

Finally it goes on to show how the wholesale rejection of Nostra aetate by the Society of St Pius X has led to schism.

Keywords: Nostra aetate, interreligious relations, 'true and holy', Society of St Pius X

\section{Bibliography}

Congar Y., Mon Journal du Concile, Vol II. présenté et annoté par E. Mahieu. Paris 2002. Council Daybook Vatican II. ed. by F. Anderson, Washington DC, 1965.

History of Vatican II, ed. by G. Alberigo, English version ed. by J. A. Komonchak, Maryknoll, NT 2006.

Internet: VIS/Apic/Imedia/Zenit/KTO/fsspx.org - DICI (03.11.11).

Internet: FSSPX/MG - DICI n²43 du 28/10/11.

John Paul II, Novo millenio ineunte. 6 January 2000.

Laurentin R., Bilan du concile, Histoire-textes - commentaires avec une chronique de la quatrième session. Paris 1966.

Lefebvre M., 'Postface', in: D. Le Roux, Peter, Lovest Thou Me? John Paul II: pope of tradition or pope of revolution? Gladysdale, Vic. 1989. No page number.

Masson J., 'La déclaration sur les religions non-chrétiennes', "Nouvelle Revue Théologique" 87 (1965) 1066-1083.

Nolan A. M., A privileged moment: dialogue in the language of the Second Vatican Council, 1962-1965. New York 2006.

Ocáriz F., The Tablet. 10 December 2011.

Oesterreicher J. M., 'Declaration on the Relationship of the Church to Non-Christian Religions,' in: Commentary on the Documents of Vatican II. ed. by Herbert Vorgrimler, New York-London 1967-1969.

Oesterreicher J. M., The new encounter between Christians and Jews. New York 1986. 
Paul VI, 'On the Church' (Ecclesiam suam), 6 August 1964.

Paul VI, 'The Government of the Universal Church (Regimini Ecclesiae), 15 August 1967.

Pius XII, 'Evangelii Praecones', “Acta Apostolicae Sedis” 1951, pp. 497-528, Official French translation in "Nouvelle Revue Théologique” 73 (1951), pp. 854-868.

Ruokanen M., The Catholic doctrine of non-Christian religions according to the Second Vatican Council. Leiden 1992.

Tissier De Mallerais B., The biography, Marcel Lefebvre. Kansas City, Missouri 2004.

Vatican II, Decree on the Apostolate of Lay People (Apostolicam actuositatem), 18 November 1965.

Vatican II, Dogmatic Constitution on the Church (Lumen gentium), 21 November 1964.

Vatican II, Pastoral Constitution on the Church in the Modern World (Gaudium et spes), 7 December 1965.

Vatican II. Decree on the Church's Missionary Activity (Ad Gentes Divinitus), 7 December 1965.

Wiltgen R. M., The rhine flows into the Tiber, New York 1966. 